\title{
Educating managers for the future
}

\author{
J.S. Goodwin and R.M. Fulmer \\ Emory University, Atlanta, Georgia
}

The authors predict that South Africa will need approximately 200000 new executives within the next 15 years. Simultaneously the organizations will become more complex and difficult to manage. They suggest that the development of such a large number of managers within the black and white community will be difficult and furthermore, managers will also require new knowledge. Even highly trained professionals may quickly become obsolete unless they continue to receive further training and development. Future-oriented courses are already being developed and taught in a number of overseas universities. The authors suggest four approaches to this future orientation: studying of future trends and projections, coping with rapid change, impact analysis, and scenario writing.

S. Afr. J. Bus. Mgmt. 1985, 16: $200-203$

Die skrywers van hierdie artikel voorspel dat Suid-Afrika binne die volgende 15 jaar bykans 200000 nuwe uitvoerende beamptes sal moet ontwikkel om aan die behoeftes van organisasies te voldoen. Terselfdertyd sal organisasies egter meer kompleks en moeilik bestudeerbaar word. Nie alleen sal die ontwikkeling van so 'n groot getal bestuurders problematies wees nie, maar bestuurders sal ook nuwe kennis benodig. Selfs hoogsopgeleide bestuurders sal vinnig onbruikbaar raak tensy hulle voortdurend aan nuwe opleiding en opvoeding blootgestel word. Toekomsgerigte curricula word alreeds aan verskeie oorsese universiteite ontwikkel en aangebied. Die skrywers stel vier benaderings tot hierdie toekomsgerigte opleiding voor: indringende studie van toekomstige tendense en voorspellings, metodes om tred te hou met veranderinge, impakanalise en die skryf van moontlike scenarios.

S.Afr. Tydskr. Bedryfsl. 1985, 16: 200-203
In Karl Marx's last, unfinished volume of Das Kapital he predicted the imminent demise of what we now call capitalism based on the 'inexorable law of the diminishing productivity of capital'. Marx's theory has been challenged numerous times. Nikolai Kondratieff, a Russian economist, published a number of reports in the 1920 s regarding 'long-wave cycles' (Martino, 1985:23). He asserted that capitalist economies undergo self-correcting cycles of approximately 54 years' length rather than self-destructing. However, from management's perspective a more important attack on Marx's theory may be found in Frederick Taylor's discovery in the late 1800s of the fact that work could be managed and thereby made more productive. Peter Drucker (1980:16) concluded that Taylor's findings are applicable to all resources. He suggested that management is responsible for the appropriate use of all resources, including human resources, and the level of their productivities.

At this time, Drucker's conclusion would appear to be of great importance in South Africa, particularly with respect to managerial resources. In the next 15 years, approximately 200000 new executives will be needed in South Africa. The net addition from the white population will probably not exceed 40000 (Black, 1984:1). Thus, productivity of current executives must be raised to the highest possible levels while developing and training substantial numbers of managers from the other ethnic groups.

This task is complicated by events now taking place in our business organizations, economies, societies, and the world. Our organizations are becoming more complex and difficult to manage. Simultaneously, change is occurring at an increasingly rapid pace. Alvin Toffler (1970:11) described our response to this phenomenon as 'future shock - a dizzying disorientation brought on by the premature arrival of the future'. As we develop future generations of management, we must not only provide them with management education but we must also prepare them to cope with the future.

\section{Education and the future}

During the past 20 years, both education and the future have been major growth industries. The World Future Society began in 1966 with four members. It now has over 30000 members throughout the world with a broad base of support in business, government and academia. In the early 1970s, US business spent $\$ 17$ billion annually to educate its personnel (Fulmer, 1972:41). This was approximately one-third of what the country spent on its public and private schools. A 1985 report by the Carnegie Foundation for the Advancement of Teaching estimated that over $\$ 100$ billion is spent for post-

\section{Emory University, Atlanta, Georgia 30322}

*To whom correspondence should be addressed 
secondary education in the US. Approximately $\$ 60$ billion is spent by colleges and universities with upwards of $\$ 40$ billion by corporations investing to educate their employees (Erich, 1985:6).

US companies are training and educating nearly 8 million people each year, approximately the total enrolment in America's four-year colleges and universities (Erich, 1985:2). Education has been described as the largest legal business in the United States. The trends are clearly similar in South Africa. Companies continue to invest huge sums in training and development even in the face of prolonged economic difficulties. The South African government also acknowledges the importance of this problem by supporting the business community's efforts with substantial subsidies.

Educators are correctly placing a greater emphasis on the necessity of turning education's focus to the future rather than the past. The skill and knowledge requirements of educated people change rapidly. The concept of life-long learning is becoming deeply embedded into our national value systems. The changing nature of technology in the work-force is placing new demands on an ageing work-force. Because of demographics and the changing nature of the economy in the US, most individuals will wait twice as long for a promotion during the next decade as they did in the 1960s (Patton, 1981:64). People who wish to receive those scarce promotions must have the ability to adapt to a changing world and conscientiously plan to keep their skills up to date. In South Africa the situation is reversed. A substantial shortfall of executives will necessitate more rapid promotion and greater responsibility. Even though the situation is not the same, the requirement is the same. Greater skills and adaptability to a changing environment are necessary. The obvious challenge to educators training personnel, and indeed, to all managers is to prepare their students and subordinates for the future instead of the past.

The knowledge revolution is behind the major shift in the world economy. This revolution has led to productivity gains through 'working smarter, not harder'. One outcome has been the more efficient use of natural resources, learning to do more with less. New business has developed through technological advances rather than simply increased production. Thus the chief catalyst of the knowledge revolution has been 'brain power' - ideas and human resources, rather than natural resources. The assertion that the average human being uses about $10 \%$ of his or her mental capability remains largely unchallenged. If we are to compete in a global marketplace, we must do an even better job of utilizing brain power; the ultimate natural resource.

\section{Impact on training}

As South Africa shifts from a society based on natural resources to one based on human resources, the importance of training and education for all organizations will increase tremendously. Even the highly educated professional can quickly become obsolete.

When managers stop learning, they are finished. During the next decade, agencies, associations, and businesses must be prepared to shoulder a significant portion of the educational responsibility for their constituents. The average college graduate entering the field of business today has hardly completed his or her education. Even if armed with an MBA, a young person's education - even formal education - has scarcely begun. A manager may return to a university for several weeks of full-time study two to three times during a career. For example, a person who attends a three-week management programme at UCT or UNISA, may in four or five years be a participant in the six-week Executive Development Programme or the two-week Senior Executive Programme at Wits Business School or the Advanced Executive Programme at UNISA. These periods of extended formal study will also be supplemented by an increasing number of short courses and seminars. Some leading firms, like IBM and Unilever, already require that every manager spend at least 40 hours per year in some form of educational activity each year. In a 1985 study involving the Fellows of the Academy of Management (a group of distinguished senior business professors who are recognized as having made significant contributions to their discipline) predicted that the average manager in the year 2000 will spend 82 hours per year in educational activities (Fulmer, 1985). IBM, generally recognized as one of the best-managed firms in the world, already spends $\$ 700$ million yearly on educational activities (Erich, 1985:8).

\section{Focus on the future}

As it exists today, management education or training is generally focused on one of four levels.

\section{The past}

Probably the most common (and least valuable) is consideration of the past - how it used to be done. Sometimes trainers or instructors believe that they have discharged their responsibility by merely recounting the techniques and practices they observed during their last exposure to a business setting. Despite the obvious obsolescence of this approach, probably $40 \%$ of formal management education is handled in this manner. Although it need not be totally historical, the case method frequently emphasizes the importance of looking at what others have done. Important lessons can be drawn from the past, but it is most important for management training to focus on the time when the trainee will be asked to use his or her skills.

\section{The theoretical}

In colleges and universities, a significant portion of instruction is focused on the theoretical. With proliferation of abstract theories and an alarming increase in the number of business professors with no practical experience, this category appears to be growing. We estimate that this emphasis may be found in $25 \%$ of all programmes. In the Delphi study previously cited, Professor Leon Meggison commented, 'the gap between academic theory and practice is probably wider than it has been in my 35 years of college training' (Fulmer, 1985:5). While corporate programmes may be criticized for this failure, corrections are usually made relatively quickly. The test of the market place prevents educators being given return assignments for corporate-sponsored programmes if their presentations do not meet some test of relevance.

\section{The future}

Managers are educated today, but they do not practise their art until tomorrow. Consequently, management training and education should be future-oriented. However, before plunging headlong into a new fad, we must carefully examine the problems and difficulties associated with a future-oriented approach.

Although it is often possible to predict the skills and techniques that workers will be using for the next few months or years, it is far more difficult to know what managers will need over the long run of five, ten or twenty years. Even more 
difficult is teaching managers exactly what they will need to perform their jobs effectively, at any given point in the future. Perhaps this is not even the key issue. The most critical factor may well be whether managers will be able to adapt and cope with tomorrow's 'brave new world'.

Whenever possible, training activities should alert learners to the actual demands they will be meeting after leaving the classroom or conference centres. But more than this, an effort must be made to prepare managers so they will be able to deal with tomorrow, regardless of what happens. Adaptability, in the future, will be second in importance only to the managerial ability to make the future become what the manager wants it to be.

\section{Future-oriented courses}

Several organizations and 'think-tanks' have developed specific courses oriented toward the future. The primary universitybased programmes in the US are offered through the Center for Futures Research at the University of Southern California. Their two major courses are entitled, 'Managing the Future', and 'Analyzing Alternative Futures'. Technology Futures Inc and the Industrial Management Centre Inc have for many years, offered three or four courses per year on technology forecasting and strategic issues management. The Battelle Institute offers several workshops on long-range forecasting using 'scenario' methods, at their Columbus, Ohio facility. Periodically, the Hudson Institute offers special programmes relating to future-oriented research they have recently completed.

Although the above brief list is not exhaustive of opportunities for study, it does provide a reasonable sample of the specialized courses available to managers with a strong interest in studying the future. Of course, the World Future Society has regular meetings on themes that are of general interest as well as with specialized themes. For example, on August 8 and 9, 1985, a programme entitled 'The Global Economy.: Today, Tomorrow, and the Transition', was conducted in Washington, DC.

\section{Training for the future}

It is impossible to develop a universal model or description of tomorrow's training procedures. No doubt scientific and technological developments will go beyond our expectations. Science fiction writers may be too tame in their projections of the amazing potential of tomorrow. Unless training and education philosophies keep pace, we are in danger of producing managers who will be close-minded and sceptical about innovative techniques.

Four approaches to future orientation are already proving successful.

\section{The crystal ball (trends and projections)}

At no other time in history has there been so much concern about forecasting the future. Government agencies, foundations, business firms, and associations are all sponsoring research concerning the long-range future. There is considerable interest in the potential of Delphi forecasting studies about the future of technological developments, social changes, or management practices. A few universities are beginning to offer courses in the future of sociology, religion, philosophy, technology, and management. Several years ago, Kaiser Aluminium developed a game called 'The Future' that was used for training purposes.

During the past two years, we have used a 'Mini-Delphi Forecasting Exercise' that asks participants to answer ten specific questions about future trends. After making their individual forecasts, participants move into groups where they reach group consensus on these same items. After group consensus is achieved, they are asked to score both their individual and group answers according to an answer sheet based on deviations from a futurist's answer. In addition to the added impact of active involvement in the learning process, the exercise reinforces the contributions of group involvement in solving difficult problems - 80\% of the almost 4000 individuals who have participated in this exercise have done better as members of a group than when they were operating individually. Corporate and university-based training programs are finding that a factual discussion of future trends and projections can be a stimulating way to end a developmental activity.

\section{Rx for future shock (coping with change)}

Change is the only constant that today's manager can expect in tomorrow's world. The rapidity of change has led to the widespread recognition of the phenomenon Alvin Toffler has profitably called 'future shock'. Even where it is impossible to inform managers about specific characteristics of the future, it is possible to prepare them for the phenomenon of change. In addition to the well-established literature concerning the significance and extent of probable change, the reasons people resist change, and ways to overcome this resistance, it is possible to involve training participants in simulated situations that give them a chance to test their adaptability to unusual and unexpected situations.

One simple way to develop coping skills is to ask groups of three or four participants to discuss the impact of an unexpected development. Examples of this might include, 'How would your organization be affected if, at age forty, people began to reverse the ageing process and regress toward childhood?'

Another illustration might deal with the impact of legislation that allowed only women to own property of any kind. Obviously, variations of this exercise are unlimited. A few minutes spent asking questions relating to the improbable can often clear mental cobwebs and make participants better prepared to accept the more formal findings of behavioural sciences as they relate to change.

\section{Impact analysis (what happens if)}

Just as planners use impact analysis as a means of assessing what the implications are of potential changes, management development educators can benefit by asking participants to anticipate the consequences of potential trends. For example, learners might be asked to assess the human resource implications of such trends as the fact that the minority composition of the workforce will increase $25 \%$ during this decade, and the divorce rate is $49 \%$ of the marriage rate, or that $70 \%$ of the work-force in 1990 will be between the ages of 25 and 55. Another approach is to take company or industry-specific trends and ask participants to discuss, in small groups, the potential implications of significant changes in resource availability, production technology, emerging forms of competition or global impacts on their business. These exercises have the combined advantage of providing practice and flexible thinking as well as providing the potential for practical insights that might solve actual problems.

\section{Inventing the future (scenario writing)}

Because management trainees will be asked to practise their skills of supervision in a world that does not yet exist, it may 
be appropriate to ask them to plan or even invent the world they expect to manage. Futurists at the Hudson Institute, Batelle Institute, the Institute for the Future, and other thinktanks have long advocated the practice of scenario writing - that is, writing brief descriptive scenes of a probable future. In 1984, the Harvard Business School added a course in scenario analysis. Designed to supplement the strategic planning process, this course built on the experience of business firms such as Shell International, who have successfully used scenarios as a foundation for planning activities.

To determine the degree to which students have thought about the future and to help stimulate their thinking along this line, it is often useful to ask them to describe their organization in a distant year such as $2000 \mathrm{AD}$. It is also useful to ask individuals to describe their own personal situation 10 or 15 years into the future. Often this exercise can dramatize a lack of creative long-range planning, as well as the difficulties involved in trying to plan for the distant future.

\section{Conclusion}

Managers ought to have some idea of where they expect to be in the future and what role their organization will be playing. Unless they have some general ideas on this subject, today's decisions may be creating a Frankensteinian future. Seneca once observed, "If a man knows what harbour he seeks, any wind is the right wind'. Today, it would be more accurate to say that for a person or group, every wind is likely to be the wrong one. Training that points to the past is obviously obsolete. The revolutionary changes and challenges that exist today will not wait for us to make up our minds. As Robert Blakely suggests, "It is not enough to modernise - to catch up with the present - the present doesn't live here anymore!'

\section{References}

Black, S. 1984. The Development and Promotion of Black Employees. Bus. Alert, April, p.1.

Drucker, P.F. 1980. Managing in Turbulent Times. New York: Harper and Row.

Erich, N.P. 1985. Corporate classrooms: The Learning Business. New Jersey, Princeton: Carnegie Foundation for the Advancement of Teaching.

Fulmer, R.M. 1972. The future of Training for the future. Training in Business and Industry, February p.41.

Fulmer, R.M. 1985. A scorecard for Management Predictions. Emory University, Working Paper Series.

Martino, J.P. 1985. Does the kondratieff wave really exist? The futurist, February, p.213.

Patton, A. 1981. The Coming Promotion Slowdown. Harv. Bus. Rev., March/April, p.64.

Toffler, A. 1970. Future Shock. New York: Random House, p.11. 